\title{
Multicenter Prospective Cohort on Aortic Valve Stenosis in Japanese Patients With End Stage Kidney Disease in Tokai Region (ASKIT)
}

Yuji Sasakawa ( $\sim$ i_xxtroubledwaterxx_335@hotmail.co.jp)

Fujita Health University Bantane Hospital

\section{Naoki Okamoto}

Fujita Health University Bantane Hospital

Maya Fujii

Fujita Health University Bantane Hospital

Jyoichiro Kato

Fujita Health University Bantane Hospital

\section{Yukio Yuzawa}

Fujita Health University

\section{Daijo Inaguma}

Fujita Health University Bantane Hospital

\section{Research Article}

Keywords: Dialysis, Aortic valve stenosis, Aortic valve calcification, Phosphorus

Posted Date: November 2nd, 2021

DOI: https://doi.org/10.21203/rs.3.rs-968136/v1

License: (1) This work is licensed under a Creative Commons Attribution 4.0 International License. Read Full License 


\section{Abstract}

\section{Background:}

The prevalence of aortic valve stenosis (AS) in patients on maintenance dialysis is high and the prognosis is poor. Because only few large cohort studies have analyzed patients with AS on dialysis, the factors that cause AS in such patients remain unclear.

\section{Methods:}

This multicenter, prospective cohort study included 2,786 patients on dialysis who underwent transthoracic echocardiography between July 1, 2017 and June 30, 2018. Patients with a maximum aortic jet velocity $(V \max ) \geq 2.0 \mathrm{~m} / \mathrm{s}$, pressure gradient $(\mathrm{PG})$ between the left ventricle and ascending aorta (mean PG) $\geq 20 \mathrm{mmHg}$, or aortic valve area (AVA) $\leq 1.0 \mathrm{~cm}^{2}$ were categorized into the AS group. Of these, patients with $V \max \geq 3.0 \mathrm{~m} / \mathrm{s}$, mean $P G \geq 20 \mathrm{mmHg}$, or AVA $\leq 1.0 \mathrm{~cm}^{2}$ were categorized into the severe AS group. The AS and severe AS groups were then compared with the non-AS group to identify the risk factors for AS using multivariate logistic analysis. We also compared the risk factors for AS with and without aortic valve calcification, which is the stage prior to age-related AS.

\section{Results:}

Of the 2,786 patients analyzed, 555 (20.0\%) and 139 (6.9\%) were categorized into the AS and severe AS groups, respectively. Multivariate logistic analysis revealed that aging, long-term dialysis, and elevated serum phosphorus levels were associated with AS in the AS and severe AS groups $(p<0.05)$. Additional investigation using stratified multivariate analysis revealed that groups with serum phosphorus levels of $5.0-5.9 \mathrm{mg} / \mathrm{dL}$ and $>6.0 \mathrm{mg} / \mathrm{dL}$ had a higher risk of AS than those with serum phosphorus levels of $<4.0$ $\mathrm{mg} / \mathrm{dL}$ (odds ratio: 2.24; $\mathrm{p}=0.01$ and odds ratio: 2.66, $\mathrm{p}=0.005$, respectively). Aortic valve calcification was associated with aging, long-term dialysis, diabetes mellitus, administration of vitamin $D$ receptor activators, elevated serum calcium levels, and anemia ( $p<0.05$ for all).

\section{Conclusions:}

Dialysis patients had a high prevalence of AS, and AS was associated with aging, long dialysis duration, and elevated serum phosphorus levels.

Trial registration: UMIN000026756, Registered on March 29, 2017.

\section{Background}

Chronic kidney disease (CKD) is known as a serious risk factor for cardiovascular disease (CVD).(1-5) Among dialysis patients, the prevalence of CVD, particularly aortic valve stenosis (AS), was reported to range from $13-25 \%,(6,7)$ which is higher than the $2.3-4.3 \%$ prevalence in the general elderly population. $(8,9)$ Previous clinical studies have reported that AS in patients undergoing dialysis is characterized by a 
rapid decrease in the aortic valve area (AVA) and a rapid progression of aortic valve calcification. $(10,11)$ In addition, patients with AS and CKD have been reported to have a lower survival rate than those without CKD. $(12,13)$

In the general population, age-related changes of the aortic valve, which gradually develops sclerosis and calcification,(14) have replaced rheumatic fever as the main cause of AS.(15) Morphological changes in the aortic valve are triggered by several factors, which include mechanical stress, endothelial damage, inflammation, and valve hemorrhage.(16) Consequently, the aortic valve leaflet becomes thickened, fibrotic, and calcified, leading to stenosis. However, the mechanisms involved remain unclear. While some studies have pointed out aging, male gender, hypertension, dyslipidemia, and smoking as factors that cause valve degeneration, $(9,17,18)$ other studies have rejected hypertension, dyslipidemia, diabetes mellitus, or renal insufficiency as factors that promote AS.(19-21) Currently, there is no consensus as to the risk factors that promote the development of AS.

Patients undergoing dialysis have a higher prevalence of hypertension, diabetes mellitus, and Mineral and Bone Disorder (MBD) than the general population. These conditions are associated with arteriosclerosis and CVD;(22-28) however, it is unclear if they are associated with AS because there are no large cohort studies that have examined the factors that influence the development of AS in patients undergoing dialysis. Therefore, we conducted a multicenter prospective cohort study to investigate the factors related to AS, the prevalence of AS, and the prognosis of patients undergoing dialysis with AS. In this report, we analyzed the results obtained at the baseline.

\section{Materials And Methods}

\section{Study Population}

This study is a prospective multicenter observational study of patients undergoing maintenance dialysis. The subjects are patients aged 20 years or older who had been undergoing outpatient maintenance dialysis for over a year at 58 hospitals in the Tokai region of Japan. The baseline was set at the time of transthoracic echocardiography (TTE) between July 1, 2017 and June 30, 2018. Patients who had previously undergone aortic valve surgery and who did not agree to be part of this study were excluded. We enrolled 2,786 patients and collected their background, history, comorbidities, medications, laboratory data, chest X-ray results, electrocardiogram tracings, and TTE images. Of the 2,786 patients, 130 patients were excluded because the duration of dialysis was less than a year, the initiation of dialysis was unknown, the aortic valve surgery had been performed, or the TTE was performed outside the observation period.

\section{Definition of aortic stenosis}

The AS parameters were measured using TTE and performed at each hospital. We obtained the maximum aortic jet velocity (Vmax), pressure gradient (PG) between the left ventricle and ascending aorta (mean PG), and AVA to evaluate AS. We defined AS based on the 2014 American Heart 
Association/American College of Cardiology (AHA/ACC) Guidelines for the Management of Patients with Valvular Heart Disease. AS was defined as 1) Vmax $\geq 2.0 \mathrm{~m} / \mathrm{s}$, or 2) Mean $P G \geq 20 \mathrm{mmHg}$, or 3) AVA $\leq 1.0$ $\mathrm{cm}^{2}$. The patients who met any of the criteria were classified into the AS group; otherwise, they were classified into the non-AS group. Of 555 patients in the AS group, 514 (92.6\%) met the condition of Vmax $\geq 2.0 \mathrm{~m} / \mathrm{s}, 107$ (19.3\%) met mean PG $\geq 20 \mathrm{mmHg}$, and 102 (18.6\%) met AVA $\leq 1.0 \mathrm{~cm}^{2}$. Based on this result, we newly classified the severe AS group, which changed the standard of Vmax from $\geq 2.0 \mathrm{~m} / \mathrm{s}$ to $\geq 3.0 \mathrm{~m} / \mathrm{s}$ without changing the standard of mean PG and AVA. Of 193 patients in the severe AS group, 98 (50.8\%) met $V \max \geq 3.0 \mathrm{~m} / \mathrm{s}, 107$ (55.4\%) met mean $P G \geq 20 \mathrm{mmHg}$, and 102 (52.8\%) met AVA $\leq 1.0$ $\mathrm{cm}^{2}$. Figure 1 shows the process of the enrollment and classification of the patients into the different groups.

\section{Statistics}

Baseline data were presented as mean (standard deviation), median (interquartile range), or percentage for categorical measures in patients. We used Fisher's exact test for nominal variables and the MannWhitney U test for continuous variables to compare the baseline data of the AS group with that of the non-AS group, and that of the severe AS group with that of the non-AS group. For the multivariate Cox regression, we performed a univariate analysis to extract factors associated with AS and added factors associated with MBD to them. We defined a model that included the gender, age, duration of dialysis, nephrosclerosis as the primary cause of CKD, diabetes mellitus as a comorbidity, use of calcimimetics, use of vitamin D receptor activators, use of phosphate binders, serum albumin level, serum corrected calcium level, serum phosphorus level, serum intact parathyroid hormone level, serum C-reactive protein level, and serum hemoglobin level. For the stratified multivariate Cox regression, we divided the patients into 4 categories based on their age: $<60,60-69,70-79$, and $\geq 80$ years. We also divided the patients into 4 categories based on their dialysis duration and serum phosphorus level: $<5,5-9,10-14$, and $\geq 5$ years, and $<4.0,4.0-4.9,5.0-5.9$, and $\geq 6.0 \mathrm{mg} / \mathrm{dL}$, respectively. All statistical analyses were performed using EZR (Saitama Medical Center, Jichi Medical University, Saitama, Japan), which is a graphical user interface for $R$ (The R Foundation for Statistical Computing, Vienna, Austria).(29) Two-sided values of $p$ $<0.05$ were considered statistically significant in all analyses.

\section{Results}

\section{Baseline characteristics}

A total of 2,786 patients were enrolled; 555 patients (20.0\%) were defined as the AS group and 2,231 $(80.0 \%)$ were defined as the non-AS group. Among the patients in the AS group, 193 patients $(6.9 \%)$ were classified into the severe AS group. Table 1 shows the baseline characteristics of the patients. The median ages of the AS, severe AS, and non-AS groups were 75, 77, and 68 years, respectively. The median hemodialysis duration of the AS, severe AS, and non-AS groups were 8.0, 7.4, and 6.2 years, respectively. The prevalence rates of diabetes mellitus in the AS, severe AS, and non-AS groups were $36.0 \%, 39.9 \%$, and $46.0 \%$, respectively. There was no significant difference in the average serum phosphorus and serum- 
corrected calcium levels among the three groups. For the TTE results, the aortic valve calcification rates in the AS and severe AS groups were $80.7 \%$ and $83.8 \%$, respectively, which were higher than the $53.3 \%$ in the non-AS group. 
Table 1

Baseline characteristics of the non-AS, AS, and severe AS groups

\begin{tabular}{|c|c|c|c|c|}
\hline $\begin{array}{l}\text { Non-AS } \\
\text { Group }\end{array}$ & AS Group & $p$ value & $\begin{array}{l}\text { Severe AS } \\
\text { Group }\end{array}$ & p value \\
\hline & & $\begin{array}{l}\text { (vs Non- } \\
\text { AS) }\end{array}$ & & $\begin{array}{l}\text { (vs Non- } \\
\text { AS) }\end{array}$ \\
\hline
\end{tabular}

\section{Basic Characteristics}

\begin{tabular}{llllll} 
Male, $\%$ & 67.0 & 63.6 & 0.13 & 59.6 & 0.04 \\
\hline Age, years & $68(59-75)$ & $75(68-82)$ & $<0.001$ & $77(70-83)$ & $<0.001$ \\
\hline Dialysis duration, years & $\begin{array}{l}6.2(3.1- \\
12.4)\end{array}$ & $\begin{array}{l}8.0(3.1) \\
15.1)\end{array}$ & $<0.001$ & $\begin{array}{l}7.4(4.0- \\
14.8)\end{array}$ & 0.005
\end{tabular}

\section{Primary Disease}

Nephrosclerosis, \%

11.9

17.3

0.001

16.6

0.07

Diabetic nephropathy, \%

39.8

29.5

$<0.001$

31.6

0.03

Chronic glomerulonephritis, \%

19.5

23.8

0.03

23.8

0.16

\section{Comorbidity}

Diabetes mellitus, $\%$

46.0

36.0

$<0.001$

39.9

0.11

Admission due to $\mathrm{HF}<1$ year, $\quad 2.0$

$\%$

5.2

$<0.001$

8.3

$<0.001$

Percutaneous coronary

intervention, \%

10.8

15.5

0.003

16.1

0.03

Coronary artery bypass

grafting, \%

4.7

6.7

0.07

9.3

0.01

Aortic disease, \%

4.8

10.8

$<0.001$

14.0

$<0.001$

\section{Usage rate of medicine} related to MBD

Vitamin D receptor activators, $\%$

Calcimimetics, \%

34.9

35.5

0.80

38.3

0.35

Phosphate binders, \%

84.7

78.6

$<0.001$

77.2

0.01

Blood Test

Data are presented as the mean \pm standard deviation or percentages. Age, dialysis duration, intact PTH, and C-reactive protein are expressed as the median (interquartile range). Abbreviations:

Admission due to $\mathrm{HF}<1$ year, admission due to heart failure within 1 year before echocardiography; LVDd, left ventricular end-diastolic diameter; LVDs, left ventricular end-systolic diameter. 


\begin{tabular}{|c|c|c|c|c|c|}
\hline & $\begin{array}{l}\text { Non-AS } \\
\text { Group }\end{array}$ & AS Group & p value & $\begin{array}{l}\text { Severe AS } \\
\text { Group }\end{array}$ & $\mathrm{p}$ value \\
\hline Corrected Calcium, mg/dl & $9.1 \pm 0.6$ & $9.1 \pm 0.6$ & 0.16 & $9.1 \pm 0.7$ & 0.55 \\
\hline Phosphorus, mg/dl & $5.3 \pm 1.3$ & $5.2 \pm 1.2$ & 0.76 & $5.2 \pm 1.2$ & 0.59 \\
\hline Intact PTH, pg/ml & $\begin{array}{l}132(80- \\
193)\end{array}$ & $\begin{array}{l}122(76- \\
185)\end{array}$ & 0.05 & $\begin{array}{l}118(76- \\
162)\end{array}$ & 0.04 \\
\hline Albumin, g/dl & $3.6 \pm 0.4$ & $3.5 \pm 0.4$ & $<0.001$ & $3.4 \pm 0.37$ & $<0.001$ \\
\hline C-reactive protein, $\mathrm{mg} / \mathrm{dl}$ & $\begin{array}{l}0.12(0.05- \\
0.37)\end{array}$ & $\begin{array}{l}0.12(0.06- \\
0.43)\end{array}$ & 0.15 & $\begin{array}{l}0.11(0.06- \\
0.55)\end{array}$ & 0.15 \\
\hline Hemoglobin, g/dl & $11.1 \pm 1.1$ & $10.9 \pm 1.2$ & $<0.001$ & $10.8 \pm 1.1$ & 0.002 \\
\hline \multicolumn{6}{|l|}{ Chest X-ray } \\
\hline Cardiothoracic ratio, \% & $50.2 \pm 5.1$ & $52.2 \pm 5.0$ & $<0.001$ & $53.0 \pm 5.0$ & $<0.001$ \\
\hline Aortic calcification, \% & 57.0 & 70.4 & $<0.001$ & 73.3 & $<0.001$ \\
\hline \multicolumn{6}{|l|}{ Electrocardiogram } \\
\hline Atrial fibrillation, \% & 5.7 & 9.6 & 0.002 & 12.0 & 0.002 \\
\hline Heart rate, /min & $74 \pm 13$ & $74 \pm 13$ & 0.91 & $75 \pm 13$ & 0.63 \\
\hline \multicolumn{6}{|l|}{$\begin{array}{l}\text { Transthoracic } \\
\text { Echocardiography }\end{array}$} \\
\hline Left atrial diameter, $\mathrm{mm}$ & $36.6 \pm 6.5$ & $38.5 \pm 6.4$ & $<0.001$ & $39.1 \pm 5.9$ & $<0.001$ \\
\hline LVDd, mm & $46.9 \pm 6.8$ & $46.9 \pm 6.1$ & 0.63 & $46.2 \pm 6.4$ & 0.26 \\
\hline LVDs, mm & $30.6 \pm 6.4$ & $30.5 \pm 6.0$ & 0.96 & $30.1 \pm 6.6$ & 0.17 \\
\hline $\begin{array}{l}\text { Left ventricular ejection } \\
\text { fraction, \% }\end{array}$ & $63.4 \pm 9.7$ & $63.5 \pm 10.0$ & 0.52 & $63.5 \pm 11.3$ & 0.37 \\
\hline Aortic valve calcification, \% & 53.3 & 80.7 & $<0.001$ & 83.8 & $<0.001$ \\
\hline $\begin{array}{l}\text { Mean pressure gradient, } \\
\mathrm{mmHg}\end{array}$ & $5.1 \pm 2.7$ & $15.5 \pm 9.6$ & $<0.001$ & $23.3 \pm 11.8$ & $<0.001$ \\
\hline Aortic valve area, $\mathrm{cm} 2$ & $2.51 \pm 0.77$ & $1.56 \pm 0.62$ & $<0.001$ & $1.08 \pm 0.46$ & $<0.001$ \\
\hline Velocity max, m/s & $1.43 \pm 0.28$ & $2.52 \pm 0.62$ & $<0.001$ & $2.96 \pm 0.87$ & $<0.001$ \\
\hline \multicolumn{6}{|c|}{$\begin{array}{l}\text { Data are presented as the mean } \pm \text { standard deviation or percentages. Age, dialysis duration, intact } \\
\text { PTH, and C-reactive protein are expressed as the median (interquartile range). Abbreviations: } \\
\text { Admission due to HF < } 1 \text { year, admission due to heart failure within } 1 \text { year before echocardiography; } \\
\text { LVDd, left ventricular end-diastolic diameter; LVDs, left ventricular end-systolic diameter. }\end{array}$} \\
\hline
\end{tabular}

2. Multivariate analysis for AS 
We included the aforementioned 14 items, which we predicted to be related to AS, as the multivariable adjusted model's factors. We performed a multivariate analysis comparing the AS and severe AS groups with the non-AS group (Table 2). In a comparison between the AS and non-AS groups, it was revealed that aging, long-term dialysis, and elevated serum phosphorus levels were associated with AS (multivariateadjusted odds ratio [MOR], 1.93; 95\% confidence interval [Cl], 1.71-2.19; $\mathrm{p}<0.001, \mathrm{MOR}, 1.41 ; 95 \% \mathrm{Cl}$, $1.21-1.64 ; p<0.001, \mathrm{MOR}, 1.16 ; 95 \% \mathrm{Cl}, 1.06-1.28 ; \mathrm{p}=0.001$, respectively). Regarding these three factors, similar tendencies were observed for the severe AS group against the non-AS group (MOR, 2.51; $95 \% \mathrm{Cl}, 2.02-3.12 ; \mathrm{p}<0.001$, MOR, 1.35; 95\% Cl, 1.06-1.71; $\mathrm{p}=0.01, \mathrm{MOR}, 1.24 ; 95 \% \mathrm{Cl}, 1.07-1.44 ; \mathrm{p}=$ 0.005 , respectively). On the other hand, nephrosclerosis as the cause of CKD was not associated with AS. Having diabetic mellitus had a significantly lower risk of AS in the AS group than the non-AS group (MOR, $0.74 ; 95 \% \mathrm{Cl}, 0.58-0.95 ; \mathrm{p}=0.02)$; however, no significant difference was found between the severe AS and non-AS group (MOR, 0.95; $95 \% \mathrm{Cl} 0.64-1.40, \mathrm{p}=0.79$ ). 
Table 2

Odds ratio for aortic valve stenosis by multivariate Cox regression

\begin{tabular}{|c|c|c|c|c|}
\hline & \multicolumn{2}{|l|}{ AS group } & \multicolumn{2}{|c|}{ Severe AS group } \\
\hline & OR $(95 \% \mathrm{Cl})$ & $\begin{array}{l}\mathrm{p} \\
\text { value }\end{array}$ & OR $(95 \% \mathrm{Cl})$ & $\begin{array}{l}\mathrm{p} \\
\text { value }\end{array}$ \\
\hline Male & $\begin{array}{l}1.02(0.81- \\
1.29)\end{array}$ & 0.86 & $\begin{array}{l}0.94(0.65- \\
1.37)\end{array}$ & 0.75 \\
\hline Age (per 10 years) & $\begin{array}{l}1.93(1.71- \\
2.19)\end{array}$ & $<0.001$ & $\begin{array}{l}2.51(2.02- \\
3.12)\end{array}$ & $<0.001$ \\
\hline Dialysis duration (per 10 years) & $\begin{array}{l}1.41(1.21- \\
1.64)\end{array}$ & $<0.001$ & $\begin{array}{l}1.35(1.06- \\
1.71)\end{array}$ & 0.01 \\
\hline $\begin{array}{l}\text { Nephrosclerosis as the primary disease of } \\
\text { CKD }\end{array}$ & $\begin{array}{l}0.94(0.67- \\
1.32)\end{array}$ & 0.72 & $\begin{array}{l}0.88(0.52- \\
1.50)\end{array}$ & 0.65 \\
\hline Diabetes complications & $\begin{array}{l}0.74(0.58- \\
0.95)\end{array}$ & 0.02 & $\begin{array}{l}0.95(0.64- \\
1.40)\end{array}$ & 0.79 \\
\hline Use of calcimimetics & $\begin{array}{l}1.16(0.91- \\
1.48)\end{array}$ & 0.24 & $\begin{array}{l}1.59(1.07- \\
2.34)\end{array}$ & 0.02 \\
\hline Use of VDRA & $\begin{array}{l}0.94(0.70- \\
1.25)\end{array}$ & 0.66 & $\begin{array}{l}0.91(0.58- \\
1.44)\end{array}$ & 0.69 \\
\hline Use of phosphate binders & $\begin{array}{l}0.87(0.65- \\
1.17)\end{array}$ & 0.35 & $\begin{array}{l}0.86(0.55- \\
1.35)\end{array}$ & 0.52 \\
\hline Corrected Calcium (per 1 mg/dl) & $\begin{array}{l}1.27(1.04- \\
1.54)\end{array}$ & 0.02 & $\begin{array}{l}1.17(0.86- \\
1.59)\end{array}$ & 0.31 \\
\hline Phosphorus (per 1 mg/dl) & $\begin{array}{l}1.16(1.06- \\
1.28)\end{array}$ & 0.001 & $\begin{array}{l}1.24(1.07- \\
1.44)\end{array}$ & 0.005 \\
\hline Intact PTH (per 10 pg/ml) & $\begin{array}{l}1.00(0.99- \\
1.01)\end{array}$ & 0.41 & $\begin{array}{l}1.00(0.98- \\
1.02)\end{array}$ & 0.91 \\
\hline Albumin (per $1 \mathrm{~g} / \mathrm{dl}$ ) & $\begin{array}{l}1.51(1.05- \\
2.17)\end{array}$ & 0.03 & $\begin{array}{l}1.04(0.58- \\
1.84)\end{array}$ & 0.91 \\
\hline C-reactive protein (per $1 \mathrm{mg} / \mathrm{dl}$ ) & $\begin{array}{l}0.98(0.89- \\
1.08)\end{array}$ & 0.67 & $\begin{array}{l}1.02(0.91- \\
1.14)\end{array}$ & 0.77 \\
\hline Hemoglobin (per $1 \mathrm{~g} / \mathrm{dl}$ ) & $\begin{array}{l}0.85(0.76- \\
0.95)\end{array}$ & 0.003 & $\begin{array}{l}0.86(0.72- \\
1.03)\end{array}$ & 0.10 \\
\hline
\end{tabular}

In addition, we divided the patients into two groups (with and without aortic valve calcification) and performed multivariate analysis (Table 3). The results showed that aortic valve calcification was 
associated with aging, long-term dialysis, diabetes mellitus, Vitamin D receptor activators (VDRA) administration, elevated serum calcium level, and anemia, but not with elevated serum phosphorus level.

Table 3

Odds ratio for aortic valve calcification by multivariable Cox regression

\begin{tabular}{|lll|}
\hline & \multicolumn{2}{l|}{ Aortic valve calcification } \\
\hline Male & OR $(95 \% \mathrm{Cl})$ & p value \\
\hline Age (per 10 years) & $0.93(0.75-1.16)$ & 0.53 \\
\hline Dialysis duration (per 10 years) & $1.70(1.54-1.88)$ & $<0.001$ \\
\hline Nephrosclerosis as the primary disease of CKD & $0.88(0.69-1.06)$ & 0.43 \\
\hline Diabetes comorbidity & $1.53(1.23-1.90)$ & $<0.001$ \\
\hline Use of calcimimetics & $0.86(0.69-1.06)$ & 0.16 \\
\hline Use of VDRA & $0.70(0.54-0.91)$ & 0.007 \\
\hline Use of phosphate binders & $0.92(0.69-1.23)$ & 0.57 \\
\hline Corrected Calcium $($ per $1 \mathrm{mg} / \mathrm{dl})$ & $1.30(1.09-1.54)$ & 0.004 \\
\hline Phosphorus $($ per $1 \mathrm{mg} / \mathrm{dl})$ & $1.03(0.95-1.12)$ & 0.46 \\
\hline Intact PTH (per $10 \mathrm{pg} / \mathrm{ml})$ & $1.00(0.99-1.01)$ & 0.56 \\
\hline Albumin (per $1 \mathrm{~g} / \mathrm{dl})$ & $1.19(0.87-1.63)$ & 0.28 \\
\hline C-reactive protein $(\mathrm{per} 1 \mathrm{mg} / \mathrm{dl})$ & $0.98(0.90-1.07)$ & 0.65 \\
\hline Hemoglobin $($ per $1 \mathrm{~g} / \mathrm{dl})$ & $0.89(0.81-0.98)$ & 0.02 \\
\hline
\end{tabular}

3. Comparison of AS parameters with and without aortic valve calcification

The mean PG, AVA, and Vmax as measured using TTE were compared between the patients with and without aortic valve calcification (Table 4). The results significantly showed that those with aortic valve calcification had characteristics of AS in all parameters. 
Table 4

Comparison of AS parameters with and without aortic valve calcification

\begin{tabular}{|lllr|}
\hline & $\begin{array}{l}\text { With } \\
\text { aortic valve calcification }\end{array}$ & $\begin{array}{l}\text { Without } \\
\text { aortic valve calcification }\end{array}$ & p value \\
\hline Velocity max, $\mathrm{m} / \mathrm{s}$ & $1.78 \pm 0.64$ & $1.51 \pm 0.50$ & $<0.001$ \\
\hline Mean pressure gradient, $\mathrm{mmHg}$ & $8.3 \pm 7.9$ & $6.3 \pm 4.8$ & $<0.001$ \\
\hline Aortic valve area, cm2 & $2.19 \pm 0.79$ & $2.50 \pm 0.90$ & $<0.001$ \\
\hline Analyses were performed using Mann-Whitney U test. & & \\
\hline
\end{tabular}

4. Stratified multivariate analysis for AS

We determined the MOR for AS between the categories of age, duration of dialysis, and serum phosphorus level (Figures 2A, 2B, and 2C). The MOR in both the AS and the severe AS groups significantly increased with age. Regarding the duration of dialysis, the MOR in the AS group tended to increase as the duration of dialysis increased. It was found that in the severe AS group, the MOR of $>15$ years of dialysis was 1.86 fold greater $(95 \% \mathrm{Cl}, 1.06-3.24 ; \mathrm{p}=0.03)$ compared to that of $<5$ years. Regarding the serum phosphorus level, the MOR tended to increase as the serum phosphorus level increased. The MORs of the categories of serum phosphorus levels of $5.0-5.9$ and $>6.0 \mathrm{mg} / \mathrm{dL}$ were 1.52 and 1.83 fold and 2.24 and 2.66 fold greater in the AS group and severe AS group, respectively, compared to that of a serum phosphorus level $<4.0 \mathrm{mg} / \mathrm{dL}$.

\section{Discussion}

In the results of this study, the prevalence of AS in dialysis patients was as high as $20.0 \%$, similar to previous reports. It was also observed that aortic valve calcification and AS are closely related. Aging had a strong effect on the development of AS in patients undergoing dialysis as well as the general population. Notably, hyperphosphatemia and long-term dialysis were found to be associated with AS.

Hyperphosphatemia is present in many patients undergoing dialysis. According to the United States Renal Data System in 2018, 38.1\% of patients undergoing dialysis in the USA had a serum phosphorus level $\geq 5.5 \mathrm{mg} / \mathrm{dL}$. According to the data from the Japanese Society for Dialysis Therapy in 2019, 53.9\% of patients undergoing dialysis in Japan had a serum phosphorus level $\geq 5.0 \mathrm{mg} / \mathrm{dL}$. Hyperphosphatemia causes CVD by promoting the calcification of vascular smooth muscle cells, resulting in a high mortality in CKD patients.(30-38) Phosphorus is thought to play a major role in the process of calcification not only in blood vessels but also in aortic valves.(39) Husseini et al. reported that SLC20A1/Pit1, a phosphorus transporter associated with calcification found in calcified blood vessels, was also expressed in calcified aortic valves.(40) In two different observational studies of approximately 100 patients undergoing dialysis, Tarrass et al. and Petrović et al. reported that phosphorus was associated with aortic valve calcification by univariate analysis and multivariate analysis, respectively. $(41,42)$ However, no 
studies have been performed that investigated the association between hyperphosphatemia and AS. In our study, an elevated serum phosphorus level was not associated with aortic valve calcification but was associated with AS. On the other hand, an elevated serum calcium level was not associated with AS but was associated with aortic valve calcification. Although we could not prove the hypothesis that hyperphosphatemia causes AS after calcification of the aortic valve, MBD, including hypercalcemia and hyperphosphatemia, was suspected to be strongly associated with aortic valve calcification and AS. Further, it is interesting to note that the group of patients with a serum phosphorus level $\geq 5.0 \mathrm{mg} / \mathrm{dL}$, which is lower than the upper limit of $6.0 \mathrm{mg} / \mathrm{dL}$ as per the Japanese guidelines, was associated with AS. This ongoing cohort study will assess the prognosis of patients with AS and concomitant hyperphosphatemia and hypercalcemia. We hope that it will help in setting target values not only for serum phosphorus levels and serum calcium levels but also in selecting phosphorus binders.

Our study showed that long-term dialysis was associated with both AS and aortic valve calcification by multivariate analysis, including aging and MBD-related factors. Because long-term dialysis involves various factors that affect the cardiovascular system, such as fluid retention, chronic inflammation, and uremic toxins, it is difficult to identify which factors induce the development of AS.(43-48) Although we cannot measure them directly, we will investigate the types of dialysis methods, such as hemodialysis, on-line hemodiafiltration, and intermittent hemodiafiltration, and the dialysis time per week to evaluate their effects on the progression of AS.

\section{Limitations}

This present study has some limitations. First, since we excluded patients having a history of aortic valve surgery, this study may have overlooked a serious risk factor for AS. Second, since we only evaluated one baseline point, the baseline results alone did not adequately assess the prognosis of AS and AS-related factors in patients undergoing dialysis. Third, because this study was a multicenter study, the accuracy of TTE was not consistent. All the above problems may be solved by comparing the annual results with the baseline results.

\section{Conclusion}

Patients on maintenance dialysis have a high prevalence of AS and a high rate of aortic valve calcification, which were associated with hyperphosphatemia and duration of dialysis. We will continue our prospective studies to evaluate the factors involved in the development and prognosis of AS in patients undergoing dialysis.

\section{Abbreviations}

chronic kidney disease (CKD)

cardiovascular disease (CVD) 
aortic valve stenosis (AS)

aortic valve area (AVA)

Mineral and Bone Disorder (MBD)

transthoracic echocardiography (TTE)

pressure gradient $(\mathrm{PG})$

maximum aortic jet velocity ( $V \max )$

multivariate-adjusted odds ratio (MOR)

confidence interval (Cl)

Vitamin D receptor activators (VDRA)

\section{Declarations}

Ethics approval and consent to participate: This study was performed according to the Ethics of Clinical Research (the Helsinki Declaration). This study was approved by Fujita Health University Center for Clinical Trial and Research Support (approval number: HM16-373). All participants involved in this study were gave informed consent after explanation of the purpose of the study and agreed to participate. This study was registered in the clinical trial registry (UMIN 000026756) on April 1, 2017.

\section{Consent for publication}

Not applicable.

\section{Availability of data and materials}

The dataset analyzed in the present study is presented in the additional file and available (title of data: dataset 1). The dataset included the patient profiles, comorbidities, medications, laboratory data, ECG, chest X-ray, and TTE.

\section{Competing interests}

D. Inaguma received lecture fees from Ono Pharmaceutical Co., Ltd. and Kyowa Kirin Co., Ltd. Y. Yuzawa received research support grants from Otsuka Pharmaceutical Co., Ltd., Kyowa Kirin Co., Ltd., and Chugai Pharmaceutical Co., Ltd. The other authors declare that they have no competing interests.

\section{Funding}

Aichi Kidney Foundation 
Japanese Association of Dialysis Physicians

\section{Authors' contributions}

DI and YS participated in the design of the study and interpretation of data. YS surveyed and collected information about prognosis. YS performed statistical analyses. YS drafted the manuscript and DI revised it critically for important intellectual content. All authors read and approved the final manuscript.

\section{Acknowledgements}

The authors acknowledge the support provided by Futoshi Suzuki (Fujita Health University), Noriko Suzuki (Fujita Health University), and the members of this cohort study. The Aichi Kidney Foundation and Japanese Association of Dialysis Physicians funded this study.

\section{References}

1. Go AS, Chertow GM, Fan D, McCulloch CE, Hsu CY. Chronic kidney disease and the risks of death, cardiovascular events, and hospitalization. N Engl J Med. 2004;351(13):1296-305.

2. Kottgen A, Russell SD, Loehr LR, Crainiceanu CM, Rosamond WD, Chang PP, Chambless LE, Coresh J. Reduced kidney function as a risk factor for incident heart failure: the atherosclerosis risk in communities (ARIC) study. J Am Soc Nephrol. 2007;18(4):1307-15.

3. Anavekar NS, McMurray JJ, Velazquez EJ, Solomon SD, Kober L, Rouleau JL, White HD, Nordlander R, Maggioni A, Dickstein K, Zelenkofske S, Leimberger JD, Califf RM, Pfeffer MA. Relation between renal dysfunction and cardiovascular outcomes after myocardial infarction. N Engl J Med. 2004;351(13):1285-95.

4. Wanner C, Amann K, Shoji T. The heart and vascular system in dialysis. Lancet. 2016;388(10041):276-84.

5. Cabrera CS, Lee AS, Olsson M, Schnecke V, Westman K, Lind M, Greasley PJ, Skrtic S. Impact of CKD Progression on Cardiovascular Disease Risk in a Contemporary UK Cohort of Individuals With Diabetes. Kidney Int Rep. 2020;5(10):1651-1660.

6. Straumann E, Meyer B, Misteli M, Blumberg A, Jenzer HR. Aortic and mitral valve disease in patients with end stage renal failure on long-term haemodialysis. Br Heart J. 1992;67(3):236-9.

7. Schönenberger A, Winkelspecht B, Köhler H, Girndt M. High prevalence of aortic valve alterations in haemodialysis patients is associated with signs of chronic inflammation. Nephron Clin Pract. 2004;96(2):c48-55.

8. Otto CM, Lind BK, Kitzman DW, Gersh BJ, Siscovick DS. Association of aortic-valve sclerosis with cardiovascular mortality and morbidity in the elderly. N Engl J Med. 1999;341(3):142-7.

9. Stewart BF, Siscovick D, Lind BK, Gardin JM, Gottdiener JS, Smith VE, Kitzman DW, Otto CM. Clinical factors associated with calcific aortic valve disease. Cardiovascular Health Study. J Am Coll Cardiol. 1997;29(3):630-4. 
10. Perkovic V, Hunt D, Griffin SV, du Plessis M, Becker GJ. Accelerated progression of calcific aortic stenosis in dialysis patients. Nephron Clin Pract. 2003;94(2):c40-5.

11. Ohara T, Hashimoto Y, Matsumura A, Suzuki M, Isobe M. Accelerated progression and morbidity in patients with aortic stenosis on chronic dialysis. Circ J. 2005;69(12):1535-9.

12. Samad Z, Sivak JA, Phelan M, Schulte PJ, Patel U, Velazquez EJ. Prevalence and Outcomes of LeftSided Valvular Heart Disease Associated With Chronic Kidney Disease. J Am Heart Assoc. 2017;6(10):e006044.

13. Zentner D, Hunt D, Chan W, Barzi F, Grigg L, Perkovic V. Prospective evaluation of aortic stenosis in end-stage kidney disease: a more fulminant process? Nephrol Dial Transplant. 2011;26(5):1651-5.

14. Lindroos M, Kupari M, Heikkilä J, Tilvis R. Prevalence of aortic valve abnormalities in the elderly: an echocardiographic study of a random population sample. J Am Coll Cardiol. 1993;21(5):1220-5.

15. lung B, Baron G, Butchart EG, Delahaye F, Gohlke-Bärwolf C, Levang OW, Tornos P, Vanoverschelde $\mathrm{JL}$, Vermeer F, Boersma E, Ravaud P, Vahanian A. A prospective survey of patients with valvular heart disease in Europe: The Euro Heart Survey on Valvular Heart Disease. Eur Heart J. 2003;24(13):123143.

16. Dweck MR, Boon NA, Newby DE. Calcific aortic stenosis: a disease of the valve and the myocardium. J Am Coll Cardiol. 2012;60(19):1854-63.

17. Rajamannan NM, Evans FJ, Aikawa E, Grande-Allen KJ, Demer LL, Heistad DD, Simmons CA, Masters KS, Mathieu P, O'Brien KD, Schoen FJ, Towler DA, Yoganathan AP, Otto CM. Calcific aortic valve disease: not simply a degenerative process: A review and agenda for research from the National Heart and Lung and Blood Institute Aortic Stenosis Working Group. Executive summary: Calcific aortic valve disease-2011 update. Circulation. 2011;124(16):1783-91.

18. Rabkin SW. The association of hypertension and aortic valve sclerosis. Blood Press. 2005;14(5):264-72.

19. Cowell SJ, Newby DE, Prescott RJ, Bloomfield P, Reid J, Northridge DB, Boon NA; Scottish Aortic Stenosis and Lipid Lowering Trial, Impact on Regression (SALTIRE) Investigators. A randomized trial of intensive lipid-lowering therapy in calcific aortic stenosis. N Engl J Med. 2005;352(23):2389-97.

20. Rosseb $\varnothing$ AB, Pedersen TR, Boman K, Brudi P, Chambers JB, Egstrup K, Gerdts E, Gohlke-Bärwolf C, Holme I, Kesäniemi YA, Malbecq W, Nienaber CA, Ray S, Skjaerpe T, Wachtell K, Willenheimer R; SEAS Investigators. Intensive lipid lowering with simvastatin and ezetimibe in aortic stenosis. $\mathrm{N}$ Engl J Med. 2008;359(13):1343-56.

21. Novaro GM, Katz R, Aviles RJ, Gottdiener JS, Cushman M, Psaty BM, Otto CM, Griffin BP. Clinical factors, but not C-reactive protein, predict progression of calcific aortic-valve disease: the Cardiovascular Health Study. J Am Coll Cardiol. 2007;50(20):1992-8.

22. Bansal N, McCulloch CE, Lin F, Robinson-Cohen C, Rahman M, Kusek JW, Anderson AH, Xie D, Townsend RR, Lora CM, Wright J, Go AS, Ojo A, Alper A, Lustigova E, Cuevas M, Kallem R, Hsu CY; CRIC Study Investigators. Different components of blood pressure are associated with increased risk 
of atherosclerotic cardiovascular disease versus heart failure in advanced chronic kidney disease. Kidney Int. 2016;90(6):1348-1356.

23. Cheung AK, Rahman M, Reboussin DM, Craven TE, Greene T, Kimmel PL, Cushman WC, Hawfield AT, Johnson KC, Lewis CE, Oparil S, Rocco MV, Sink KM, Whelton PK, Wright JT Jr, Basile J, Beddhu S, Bhatt U, Chang TI, Chertow GM, Chonchol M, Freedman BI, Haley W, Ix JH, Katz LA, Killeen AA, Papademetriou V, Ricardo AC, Servilla K, Wall B, Wolfgram D, Yee J; SPRINT Research Group. Effects of Intensive BP Control in CKD. J Am Soc Nephrol. 2017;28(9):2812-2823.

24. Haffner SM, Lehto S, Rönnemaa T, Pyörälä K, Laakso M. Mortality from coronary heart disease in subjects with type 2 diabetes and in nondiabetic subjects with and without prior myocardial infarction. N Engl J Med. 1998;339(4):229-34.

25. Tonelli M, Muntner P, Lloyd A, Manns BJ, Klarenbach S, Pannu N, James MT, Hemmelgarn BR; Alberta Kidney Disease Network. Risk of coronary events in people with chronic kidney disease compared with those with diabetes: a population-level cohort study. Lancet. 2012;380(9844):807-14.

26. Adler Al, Stevens RJ, Manley SE, Bilous RW, Cull CA, Holman RR; UKPDS GROUP. Development and progression of nephropathy in type 2 diabetes: the United Kingdom Prospective Diabetes Study (UKPDS 64). Kidney Int. 2003;63(1):225-32.

27. Kestenbaum B, Sampson JN, Rudser KD, Patterson DJ, Seliger SL, Young B, Sherrard DJ, Andress DL. Serum phosphate levels and mortality risk among people with chronic kidney disease. J Am Soc Nephrol. 2005;16(2):520-8.

28. Tentori F, Blayney MJ, Albert JM, Gillespie BW, Kerr PG, Bommer J, Young EW, Akizawa T, Akiba T, Pisoni RL, Robinson BM, Port FK. Mortality risk for dialysis patients with different levels of serum calcium, phosphorus, and PTH: the Dialysis Outcomes and Practice Patterns Study (DOPPS). Am J Kidney Dis. 2008;52(3):519-30.

29. Kanda Y. Investigation of the freely available easy-to-use software 'EZR' for medical statistics. Bone Marrow Transplant. 2013;48(3):452-8.

30. Giachelli CM, Speer MY, Li X, Rajachar RM, Yang H. Regulation of vascular calcification: roles of phosphate and osteopontin. Circ Res. 2005;96(7):717-22.

31. Shroff R, Long DA, Shanahan C. Mechanistic insights into vascular calcification in CKD. J Am Soc Nephrol. 2013;24(2):179-89.

32. Goodman WG, Goldin J, Kuizon BD, Yoon C, Gales B, Sider D, Wang Y, Chung J, Emerick A, Greaser L, Elashoff RM, Salusky IB. Coronary-artery calcification in young adults with end-stage renal disease who are undergoing dialysis. N Engl J Med. 2000;342(20):1478-83.

33. Isaka Y, Hamano T, Fujii H, Tsujimoto Y, Koiwa F, Sakaguchi Y, Tanaka R, Tomiyama N, Tatsugami F, Teramukai S. Optimal Phosphate Control Related to Coronary Artery Calcification in Dialysis Patients. J Am Soc Nephrol. 2021;32(3):723-735.

34. Block GA, Klassen PS, Lazarus JM, Ofsthun N, Lowrie EG, Chertow GM. Mineral metabolism, mortality, and morbidity in maintenance hemodialysis. J Am Soc Nephrol. 2004;15(8):2208-18. 
35. Floege J, Kim J, Ireland E, Chazot C, Drueke T, de Francisco A, Kronenberg F, Marcelli D, PasslickDeetjen J, Schernthaner G, Fouqueray B, Wheeler DC; ARO Investigators. Serum iPTH, calcium and phosphate, and the risk of mortality in a European haemodialysis population.Nephrol Dial Transplant. 2011;26(6):1948-55.

36. Ganesh SK, Stack AG, Levin NW, Hulbert-Shearon T, Port FK. Association of elevated serum PO(4), Ca $\mathrm{x} \mathrm{PO}(4)$ product, and parathyroid hormone with cardiac mortality risk in chronic hemodialysis patients. J Am Soc Nephrol. 2001;12(10):2131-8.

37. Young EW, Albert JM, Satayathum S, Goodkin DA, Pisoni RL, Akiba T, Akizawa T, Kurokawa K, Bommer J, Piera L, Port FK. Predictors and consequences of altered mineral metabolism: the Dialysis Outcomes and Practice Patterns Study. Kidney Int. 2005;67(3):1179-87.

38. Slinin Y, Foley RN, Collins AJ. Calcium, phosphorus, parathyroid hormone, and cardiovascular disease in hemodialysis patients: the USRDS waves 1, 3, and 4 study. J Am Soc Nephrol. 2005;16(6):1788-93.

39. Rattazzi M, Bertacco E, Del Vecchio A, Puato M, Faggin E, Pauletto P. Aortic valve calcification in chronic kidney disease. Nephrol Dial Transplant. 2013;28(12):2968-76.

40. El Husseini D, Boulanger MC, Fournier D, Mahmut A, Bossé Y, Pibarot $P$, Mathieu P. High expression of the Pi-transporter SLC20A1/Pit1 in calcific aortic valve disease promotes mineralization through regulation of Akt-1. PLoS One. 2013;8(1):e53393.

41. Tarrass F, Benjelloun M, Zamd M, Medkouri G, Hachim K, Benghanem MG, Ramdani B. Heart valve calcifications in patients with end-stage renal disease: analysis for risk factors. Nephrology (Carlton). 2006;11(6):494-6.

42. Petrović D, Obrenović R, Stojimirović B. Risk factors for aortic valve calcification in patients on regular hemodialysis. Int J Artif Organs. 2009;32(3):173-9.

43. Kalantar-Zadeh K, Regidor DL, Kovesdy CP, Van Wyck D, Bunnapradist S, Horwich TB, Fonarow GC. Fluid retention is associated with cardiovascular mortality in patients undergoing long-term hemodialysis. Circulation. 2009;119(5):671-9.

44. Cozzolino M, Mangano M, Stucchi A, Ciceri P, Conte F, Galassi A. Cardiovascular disease in dialysis patients. Nephrol Dial Transplant. 2018;33(suppl_3):iii28-iii34.

45. Sun J, Axelsson J, Machowska A, Heimbürger O, Bárány P, Lindholm B, Lindström K, Stenvinkel P, Qureshi AR. Biomarkers of Cardiovascular Disease and Mortality Risk in Patients with Advanced CKD. Clin J Am Soc Nephrol. 2016;11(7):1163-72.

46. Liabeuf S, Lenglet A, Desjardins L, Neirynck N, Glorieux G, Lemke HD, Vanholder R, Diouf M, Choukroun G, Massy ZA; European Uremic Toxin Work Group (EUTox). Plasma beta-2 microglobulin is associated with cardiovascular disease in uremic patients. Kidney Int. 2012;82(12):1297-303.

47. Stubbs JR, House JA, Ocque AJ, Zhang S, Johnson C, Kimber C, Schmidt K, Gupta A, Wetmore JB, Nolin TD, Spertus JA, Yu AS. Serum Trimethylamine-N-Oxide is Elevated in CKD and Correlates with Coronary Atherosclerosis Burden. J Am Soc Nephrol. 2016;27(1):305-13. 
48. Barreto FC, Barreto DV, Liabeuf S, Meert N, Glorieux G, Temmar M, Choukroun G, Vanholder R, Massy ZA; European Uremic Toxin Work Group (EUTox). Serum indoxyl sulfate is associated with vascular disease and mortality in chronic kidney disease patients. Clin J Am Soc Nephrol. 2009;4(10):1551-8.

\section{Figures}

Figure 1.

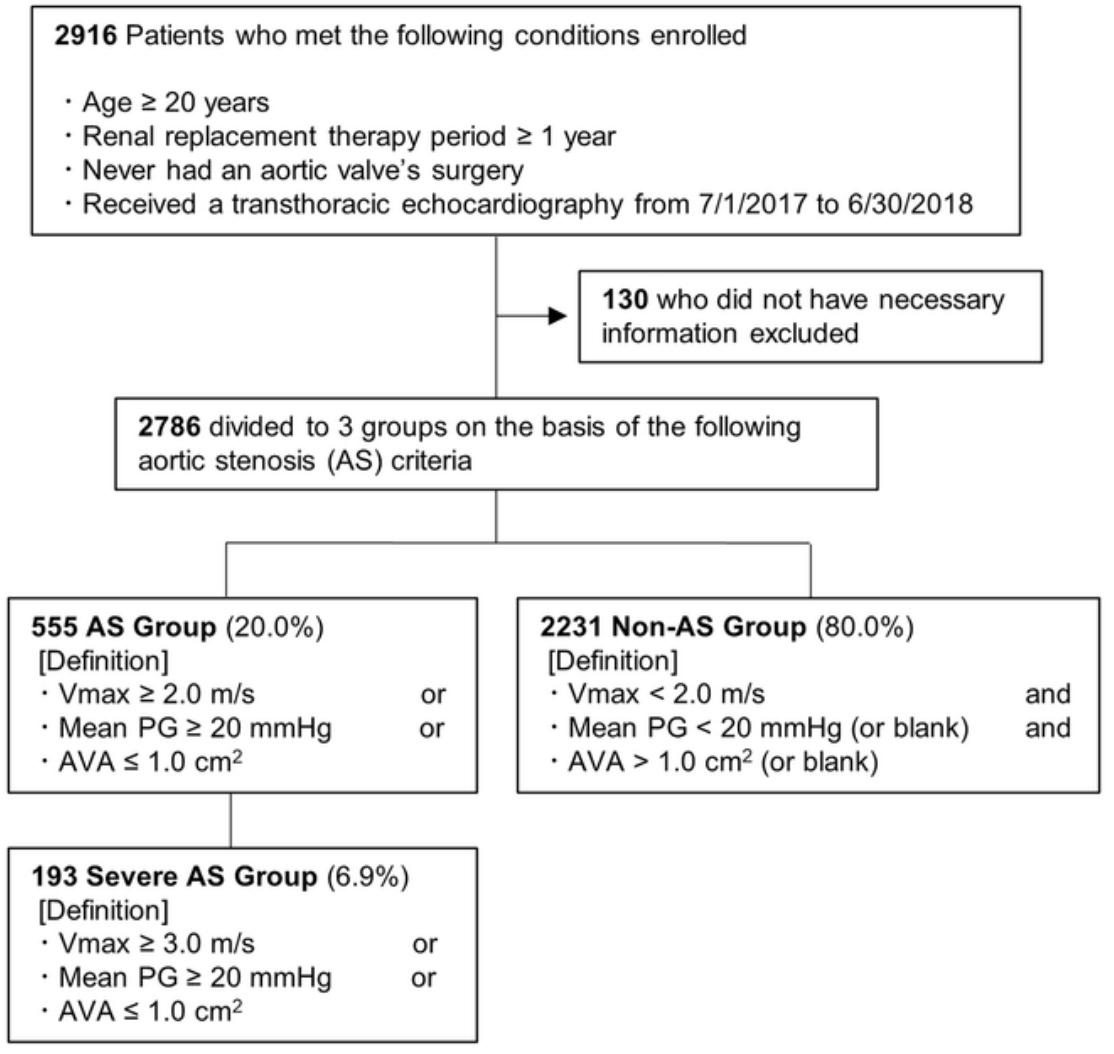


A flow diagram of the present study Abbreviations: Vmax, Velocity max; PG, pressure gradient; AVA, aortic valve area

A

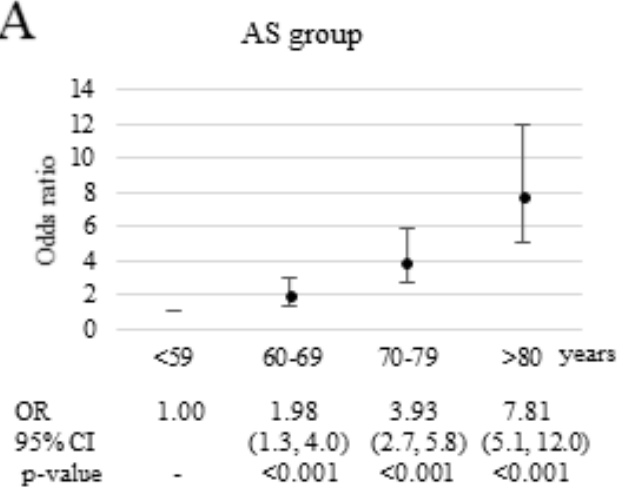

B

3

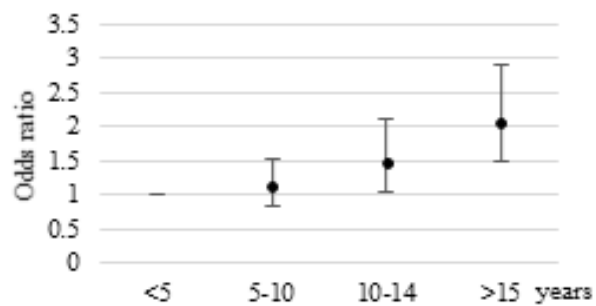

$\begin{array}{lcccc}\text { OR } & 1.00 & 1.14 & 1.48 & 2.08 \\ 95 \% \mathrm{CI} & & (0.9,1.5) & (1.0,2.1) & (1.5,2.9) \\ \text { p-value } & - & 0.39 & 0.03 & <0.001\end{array}$

$\mathrm{C}$

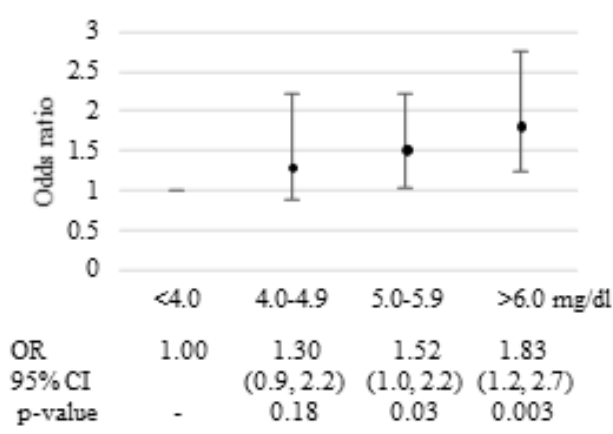

Severe AS group

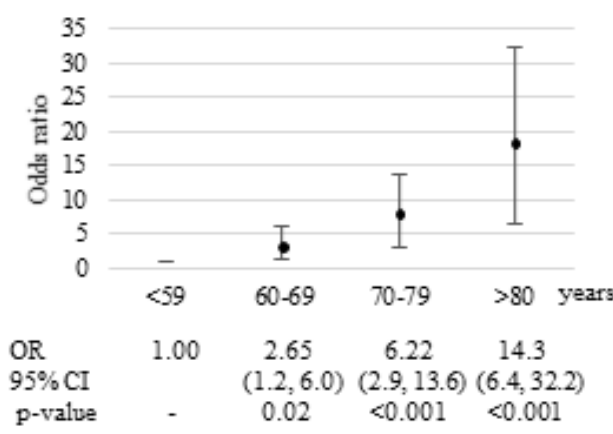

Severe AS group

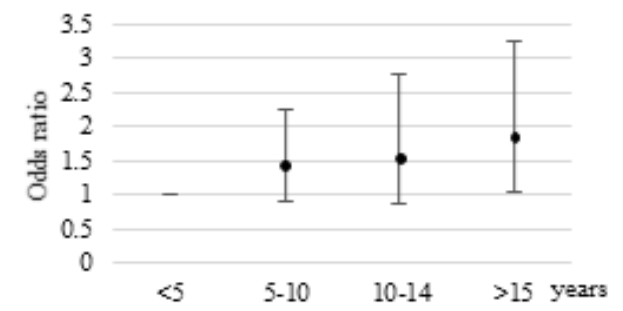

$\begin{array}{llll}1.00 & 1.44 & 1.56 & 1.86\end{array}$

$95 \%$ CI $\quad(0.9,2.3)(0.9,2.8)(1.1,3.2)$

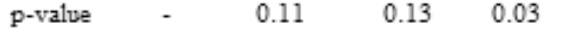

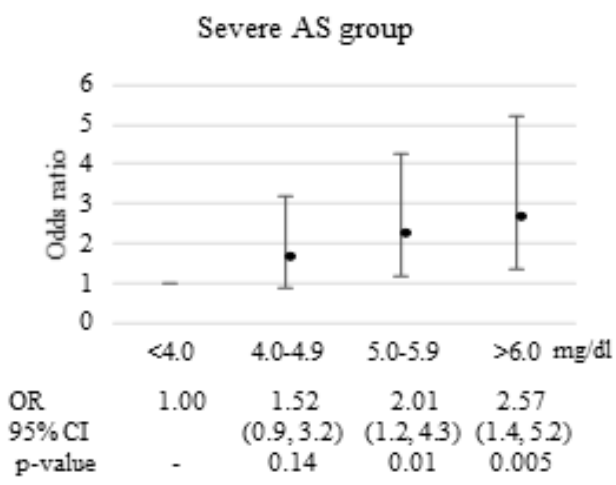

\section{Figure 2}

Multivariate-adjusted odds ratio (MOR) for AS between the categories of age, duration of dialysis, and serum phosphorus level The graph on the left was a comparison between the AS group and the non-AS group, and the graph on the right was a comparison between the severe AS group and the non-AS group. 
The multivariate analysis model included the gender, age, duration of dialysis, nephrosclerosis as the primary cause of CKD, diabetes mellitus as a comorbidity, use of calcimimetics, use of vitamin $D$ receptor activators, use of phosphate binders, serum albumin level, serum corrected calcium level, serum phosphorus level, serum intact parathyroid hormone level, serum C-reactive protein level, and serum hemoglobin level as adjustments. A: MOR for AS between the categories of age B: MOR for AS between the categories of duration of dialysis C: MOR for AS between the categories of serum phosphorus level 